\title{
The Perception of Water Quality and Related Diseases in Rural Areas of the Department of Tiassalé, Côte d'Ivoire, West Africa
}

\author{
Adidjatou Ouattara, \\ Alassane Meite, \\ Laboratory of Nutrition and Pharmacology, \\ UFR Biosciences, Félix Houphouet-Boigny \\ University of Cocody, Côte d'Ivoire \\ Theodor Dally, \\ UFR Environnement, Jean Lorougnon Guédé \\ University of Daloa, Côte d'Ivoire \\ Howele Ouattara, \\ UFR Biological Sciences, Péléforo Gon Coulibaly \\ University of Korhogo, Côte d'Ivoire \\ Seraphin Kati-Coulibaly, \\ Laboratory of Nutrition and Pharmacology, \\ UFR Biosciences, Félix Houphouet-Boigny \\ University of Cocody, Côte d'Ivoire
}

Doi:10.19044/esj.2019.v15n27p136 URL:http://dx.doi.org/10.19044/esj.2019.v15n27p136

\begin{abstract}
One of critical public health concerns in many developing countries today is water quality and the risks associated with waterborne diseases. Many research works that have studied about factors contributing to water pollution have not considered the perception on drinking water quality and health risk in the rural area of the department of Tiassalé. This study therefore focuses on evaluating the level of perception of households living in the rural area of Tiassalé. The study data were collected through interviews from a total of 600 respondents with structured questionnaire. The majority of the respondents (78.2\%) used water from hand dug wells for drinking purpose. According to $77.7 \%$ of respondents, water from the wells was safe for drinking. Around 9.3\% had a degree of knowledge about the sources of well water contamination. Majority of the respondents $(87.3 \%)$ did not treat their water. About $80 \%$ of residents mentioned that they had not experienced any negative effects from drinking the well water. Variables associated with perception of drinking water quality included educational status, use of at least one method
\end{abstract}


of water treatment, and awareness of health risks of drinking contaminated water. The results of this study indicated that knowledge on water quality and health risks were poor.

Keywords: Perception, Tiassalé, Water quality, Diseases

\section{Introduction}

Water is a natural resource whose availability in sufficient quantity and acceptable quality contributes to the maintenance of health. Although $91 \%$ coverage of drinking water has been achieved globally, and 6.6 billion people have access to improved water sources, much of the world's population, especially those living in rural areas, continue to consume water of poor microbiological quality. In sub-Saharan Africa, for instance, 319 million people live without access to an improved water source and 102 million people still use surface water.

Such type of drinking water is contaminated with heavy metals and chemicals. In addition, the bacterial and other pathogenic contents of this poor-quality, contaminated water, lead to many types of infections known to affect people who consume them. These water-related diseases, such as diarrhea, urinary infection, food poisoning, cholera, vomiting, hepatitis, gastroenteritis, typhoid, hepatitis, and more, which exist not only in undeveloped countries but also in developed countries, account for high mortality rate.

In Côte d'Ivoire, water issues are still a major problem for the population, especially those living in rural areas where only $65 \%$ have access to drinking water (INS, 2012). In the department of Tiassalé, the problem of water pollution is growing at an alarming rate. Although a number of reports have been published on drinking water, however, very few studies have been carried out regarding the perception of drinking water quality and water borne diseases.

Ensuring that the population is adequately informed on the acceptable drinking water quality are important mechanisms in the protection of public health, especially when they have been properly warned against any form of exposure to contaminated water. Regarding water crisis situations in particular, communication with the public is essential. Public perceptions of water quality have a direct influence on behaviors (Nsiah-Kumi, 2008).

There are a number of studies which indicate that the people's water perception is the main indicator for the provision of satisfactory water. These studies also suggest that the quality of water is improved based on public perception. In addition, WHO guidelines are made accordingly. In fact, perceptions of safe water have been widely recognized as having significant implications for the development of appropriate programs and policies to 
improve water management and the provision of water services as well as risk communication (Doria, 2010).

The purpose of this study was to explore in-depth the drinking water perceptions and the knowledge on water treatment as well as that of waterborne diseases of the households in the rural area in the department of Tiassalé.

\section{Materials and Methods \\ Study Area}

The study was conducted in the department of Tiassale located in the South of Côte d'Ivoire, between October and November, 2015. This location belongs to AGNEBY-TIASSA region, between $5^{\circ} 32^{\prime}$ to $6^{\circ} 24^{\prime}$ North latitude and $4^{\circ} 29^{\prime}$ to $5^{\circ} 14^{\prime}$ West longitude. This department has an area of $3,370 \mathrm{~km}^{2}$ and a population estimated to be about 81,180 women and 98,702 men. The number of households is put at 38,996 with an average size of 5 persons per household. More than half of households (68.1\%) live in rural areas compared to the $31.1 \%$ in urban areas (INS, 2014).

In the department, the majority of populations, especially in rural areas, use well water for domestic water supplies. The households are characterized by a low socioeconomic status and are located on sites lacking hygiene and sanitization infrastructure.

\section{Study Population}

Rural households were selected from eight localities of the study area. The localities were chosen because of their geographical proximity and their similarity in terms of accessibility, socioeconomic status, employment, education, and use of tube well water.

\section{Sample Size}

To calculate the sample size, the following formula was used:

$\mathrm{n}=\mathrm{t}^{2} * \mathrm{p} *(1-\mathrm{p})^{*} \mathrm{c} / \mathrm{e}^{2}$ where:

- $\mathrm{n}=$ sample size;

- $\mathrm{t}=$ Reduced gap corresponding to accepted risk (1.96);

- $\mathrm{p}=$ Estimated prevalence of the health problem or phenomenon under study

$(0.5)$;

- $\mathrm{c}=$ Correction factor $(1.5)$;

- e = Tolerated sampling error margin (0.05);

$\mathrm{n}=384.66 * 1.5$

$\mathrm{n}=577$

This figure has been rounded to 600 households. 


\section{Administration of Questionnaire}

Each household was interviewed after the purpose of the study was explained to them and after the interviewees was assured that all data would remain confidential. To survey water-related knowledge, perceptions and behavior of the population, it was important that respondents were able to freely answer. A rapid and reliable method is to obtain qualitative data through "face-to-face interviews" which in this research consisted of guided interviews with open questions, in order to facilitate the free expression of the respondents (Rojas \& Megerle, 2013).

The questionnaire was designed to take approximately 30 minutes, including open and closed questions. The questionnaire was organized into four main sections: socio-demographic and economic characteristics (e.g., gender, age, family size, instruction level, and occupation), perception of well water, water treatment, and knowledge about water-related diseases (Berhanu \& Hailu, 2015).

\section{Data Collection Technique for Assessment Perception of Water Quality}

A pre-tested, structured, self-administered questionnaire was used for the data collection. The pre-test was conducted adjacent to the study zone which had similar characteristics to the areas where the actual study was carried out. Vague terms, phrases, and questions identified during the pre-test were modified and changed. Missing responses like "no response" and "others" were added (Berhanu \& Hailu, 2015).

Data was collected from interviewing 600 participants mostly women including any other person responsible in the house. Completeness and consistency of the collected data was checked at each day of data collection.

\section{Eligibility Criteria}

Every respondent (household) from the target localities who gave their informed consent was included in the survey.

\section{Data Management and Data Analysis}

The analysis of data was conducted using Statistical Package for Social Science (SPSS) version 20. Univariate analysis was conducted. Using logistic regression, multivariate analysis was also carried out. The odds ratio and $95 \%$ Confidence Interval (CI) were used to determine the effect of potential associated variables on the perception of well water quality. The association was considered significant for independent variables with a $\mathrm{p}$-value less than 0.05 . 


\section{Ethical Considerations}

After offering an explanation about the purpose of the study, permission was obtained from the offices of department of Tiassalé and their local administration. An informed consent was also obtained from the study participants. Anonymity and confidentiality of the information was maintained throughout the data collection process.

The purpose of the study was explained to the participating household owners and verbal consent was obtained. Anyone who was not willing to participate in the study had the right to discontinue at any time in the process. Each respondent was assured that the information provided by her/him was kept confidential and used only for the purpose of this study.

\section{Results}

\section{Socio-Demographic Characteristics of the Respondents}

Socio-demographic and economic characteristics are summarized in Table 1. Respondents were predominantly female (89\%). From a total of 600 respondents of households who participated, mean $( \pm$ SD) age was $37.5( \pm 11)$ years, and more than half (61.3\%) respondents were between age $20-40$ years old. Among the total participants, $58.8 \%$ were married and concerning their educational standing, majority of the respondents $(65.5 \%)$ were illiterate (not able to read and write). Regarding the occupational status of the respondents, majority of respondents (50.9 \%) were farmers. Lastly, $39.2 \%$ of the respondents had family size of less than six individuals. 
Table 1. Socio-demographic characteristics of the respondents

\begin{tabular}{lllll}
\hline Variables & Modalities & Frequency & Percent \% & 95\% CI \\
\hline -Sex & Male & 66 & 11 & {$[8.5-13.5]$} \\
& Female & 534 & 89 & {$[86.5-91.5]$} \\
& Total & $\mathbf{6 0 0}$ & $\mathbf{1 0 0 . 0}$ & \\
-Age & $<20$ & 16 & 2.7 & {$[1.4-4.0]$} \\
& $20-40$ & 368 & 61.3 & {$[57.4-65.3]$} \\
& $41-60$ & 197 & 32.8 & {$[29.1-36.5]$} \\
-Matrimonial status & $>60$ & 19 & 3.2 & {$[1.3-4.6]$} \\
& Total & $\mathbf{6 0 0}$ & $\mathbf{1 0 0 . 0}$ & \\
& Married & 353 & 58.8 & {$[54.9-62.7]$} \\
& Unmarried & 247 & 41.2 & {$[37.3-45.1]$} \\
-School level & Total & $\mathbf{6 0 0}$ & $\mathbf{1 0 0 . 0}$ & \\
& Illiterate & 393 & 65.5 & {$[61.7-69.3]$} \\
& Primary & 130 & 21.7 & {$[18.4-25.0]$} \\
& Secondary & 61 & 10.2 & {$[7.8-12.6]$} \\
& Superior & 16 & 2.7 & {$[1.4-4.0]$} \\
& Total & $\mathbf{6 0 0}$ & $\mathbf{1 0 0 . 0}$ & \\
-Socio-Professional & Trader & 140 & 50.9 & {$[46.8-54.8]$} \\
Category & Farmer & 305 & 23.4 & {$[19.9-26.7]$} \\
& No activity & 155 & 25.7 & {$[22.3-29.3]$} \\
& Total & $\mathbf{6 0 0}$ & $\mathbf{1 0 0 . 0}$ & \\
-Family size & 1-5 & 236 & 39.2 & {$[35.3-43.1]$} \\
& 6-10 & 263 & 43.9 & {$[39.9-47.9]$} \\
& $>10$ & 101 & 16.9 & {$[13.9-19.9]$} \\
& Total & $\mathbf{6 0 0}$ & $\mathbf{1 0 0 . 0}$ & \\
\hline CI: Confide & & & \\
& & & &
\end{tabular}

CI: Confidence Interval.

\section{Public Awareness about Wells Water Quality}

The summary of awareness about well water is shown in Table 2 . Approximately $82.7 \%$ of the participants surveyed consumed water from hand-dug wells and $17.3 \%$ consumed water from boreholes. According to $77.7 \%$ of respondents, water from the wells was safe for drinking. Results of knowledge about water pollution sources are displayed in Table 2. Around 9.3\% had a degree of knowledge about well water contamination sources. 
Table 2. Awareness about well water quality

\begin{tabular}{|c|c|c|c|c|}
\hline Variables & Modalities & Frequency & Percent $(\%)$ & $95 \% \mathrm{CI}$ \\
\hline \multirow{3}{*}{$\begin{array}{l}\text {-Sources of drinking } \\
\text { water }\end{array}$} & Hand-dug wells & 496 & 82.7 & [79.9-85.7] \\
\hline & Boreholes & 104 & 17.3 & {$[14.3-20.3]$} \\
\hline & Total & 600 & 100.0 & \\
\hline \multirow{3}{*}{$\begin{array}{l}\text {-Perception on water } \\
\text { quality }\end{array}$} & Safe for drinking & 466 & 77.7 & {$[74.9-81.5]$} \\
\hline & Unsafe for drinking & 134 & 22.3 & {$[19.2-15.8]$} \\
\hline & Total & 600 & 100.0 & \\
\hline \multirow{4}{*}{$\begin{array}{l}\text {-Knowledge about wells } \\
\text { water pollution origin }\end{array}$} & Yes & 56 & 9.3 & [7-11.6] \\
\hline & No & 544 & 90.7 & [88.4-93] \\
\hline & Total & 600 & 100.0 & \\
\hline & Dead animals & 6 & 10.7 & {$[2.6-18.8]$} \\
\hline \multirow{5}{*}{$\begin{array}{l}\text {-Origin of water } \\
\text { pollution known }\end{array}$} & Wastes & 12 & 21.6 & {$[10.8-32.4]$} \\
\hline & Dirty runoff waters & 9 & 16 & {$[6.4-25.6]$} \\
\hline & Traditional latrine & 9 & 16 & [6.4-25.6] \\
\hline & $\begin{array}{l}\text { Bucket and rope to draw } \\
\text { water }\end{array}$ & 20 & 35.7 & {$[23.2-48.2]$} \\
\hline & Total & $56^{*}$ & 100.0 & \\
\hline
\end{tabular}

*Only those who had knowledge about water pollution sources. CI: Confidence Interval

\section{Knowledge of Water Treatment Methods}

According to Table 3,70\% of participants have heard about water treatment methods. With regards to water treatment before use, $12.7 \%$ of the study households use at least one water treatment method. To reduce cases of illnesses arising from drinking contaminated water, respondents mentioned some intervention measures such as adding bleach before using it (69.7\%), tissue filtration $(21.0 \%)$, and using naphthalene $(9.3 \%)$.

Table 3: Knowledge of water treatment methods

\begin{tabular}{|c|c|c|c|c|}
\hline Variables & Modalities & Frequency & Percent \% & $95 \% \mathrm{CI}$ \\
\hline -Knowledge & Yes & 420 & 70 & [66.3-73.3] \\
\hline \multirow{2}{*}{ treatment methods } & No & 180 & 30 & [26.3-33.7] \\
\hline & Total & 600 & 100.0 & \\
\hline \multirow{4}{*}{$\begin{array}{l}\text {-Use of at least one method } \\
\text { of water treatment }\end{array}$} & Yes & 76 & 12.7 & [9.5-15.9] \\
\hline & No & 524 & 87.3 & [83.9-90.5] \\
\hline & Total & 600 & 100.0 & \\
\hline & Bleach & 53 & 69.7 & [59.4-80] \\
\hline \multirow{3}{*}{$\begin{array}{l}\text {-Methods of treatment } \\
\text { of the water used }\end{array}$} & Filtration & 16 & 21.0 & [11.9-30.1] \\
\hline & Naphthalene & 7 & 9.3 & {$[2.8-15.8]$} \\
\hline & Total & $76^{*}$ & 100.0 & \\
\hline \multirow{4}{*}{$\begin{array}{l}\text {-Improving the quality of treated } \\
\text { water }\end{array}$} & Yes & 18 & 23.7 & [14.1-53.3] \\
\hline & No & 10 & 13.1 & {$[5.5-20.7]$} \\
\hline & Without opinion & 48 & 63.2 & {$[45.2-74]$} \\
\hline & Total & $76 *$ & 100.0 & \\
\hline
\end{tabular}

\footnotetext{
*Only those who claimed to have used at least one method. CI: Confidence Interval.
} 


\section{Knowledge about Waterborne Diseases}

Results regarding knowledge about waterborne diseases are shown in Table 4. About $49.6 \%$ did not know of any health risks of drinking contaminated water. Respondents mentioned diarrhea (46.3\%), vomiting (23.2\%), cholera (6.6\%), typhoid (10.6\%), dysentery (9.9\%), and fever $(3.4 \%)$ as illnesses resulting from drinking contaminated water. About $80 \%$ of residents mentioned that they had not experienced any negative effects from drinking the well water while $20 \%$ had experienced such cases.

Table 4. Awareness about waterborne diseases

\begin{tabular}{lllll}
\hline Variables & Modalities & Frequencies & Percent (\%) & 95\% CI \\
\hline -Health risks of drinking & Yes & 302 & 50.3 & {$[46.3-54.3]$} \\
contaminated water & No & 298 & 49.7 & {$[42.7-54.5]$} \\
& Total & $\mathbf{6 0 0}$ & \multicolumn{1}{c}{$\mathbf{1 0 0 . 0}$} & \\
& Diarrhea & 140 & 46.3 & {$[40.7-51.9]$} \\
-Knowledge of at least & Vomiting & 70 & 23.2 & {$[18-4-28]$} \\
one waterborne disease & Cholera & 20 & 6.6 & {$[3.8-9.4]$} \\
& Typhoid & 32 & 10.6 & {$[7.1-14.1]$} \\
& Dysentery & 30 & 9.9 & {$[6.2-13.6]$} \\
-Negative effects after & Tover & 10 & 3.4 & {$[1.4-5.4]$} \\
drinking well water & Yes & $\mathbf{3 0 2} *$ & $\mathbf{1 0 0 . 0}$ & {$[18.1-23.1]$} \\
& No & 120 & 20 & {$[77.4-83.4]$} \\
& Total & 480 & 80 &
\end{tabular}

* Only those who possessed knowledge on health risks of drinking contaminated water. CI: Confidence Interval.

\section{Factors Associated with Perception of Water Quality}

Table 5 presents the main findings of bivariate and multivariate analyses. The multivariate logistic regression model presents the unique effects of each independent variable, which is the main focus of interpretation. In examining the bivariate analysis, sex, age, matrimonial status, localities, and source of drinking water were not statistically significant in explaining the perception of water quality. Variables associated with reports of a greater perception of well water included educational status, use of at least one method of water treatment, and awareness of health risks of drinking contaminated water. 
Table 5. Factors associated with perception of water quality

\begin{tabular}{|c|c|c|c|c|c|c|}
\hline \multirow[t]{2}{*}{ Variables } & \multicolumn{2}{|c|}{ Perception of water quality } & \multicolumn{2}{|c|}{ Univariate } & \multicolumn{2}{|c|}{ Multivariate } \\
\hline & Safe & Unsafe & Crude $^{\mathrm{a}}$ OR (95\% CI) & P-value & Adjusted $^{\mathrm{b}}$ OR (95\% CI) & P-value \\
\hline \multicolumn{7}{|c|}{ 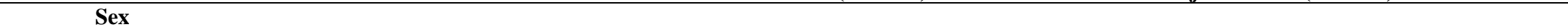 } \\
\hline Male & 56 & 10 & 1 & & & \\
\hline Female & 410 & 124 & $0.590(0.293-1.192)$ & 0.141 & & \\
\hline \multicolumn{7}{|l|}{ Age } \\
\hline$<20$ & 11 & 5 & 1 & & & \\
\hline $20-40$ & 281 & 87 & $0.681(0.230-2.014)$ & 0.488 & & \\
\hline $41-60$ & 162 & 35 & $0.475(0.155-1.455)$ & 0.192 & & \\
\hline$>60$ & 12 & 7 & $1.283(0.314-5.253)$ & 0.729 & & \\
\hline \multicolumn{7}{|l|}{ Educational status } \\
\hline Illiterate & 325 & 68 & $0.126(0.044-0.357)$ & $0.000 *$ & $0.176(0,060-0.514)$ & $0.002 *$ \\
\hline Primary & 92 & 38 & $0.248(0.084-0.730)$ & 0.011* & $0.310(0,103-0.935)$ & 0.038* \\
\hline Secondary & 43 & 18 & $0.251(0.079-0.795)$ & 0.019* & $0.317(0.098-1.031)$ & 0.056 \\
\hline Superior & 6 & 10 & 1 & & 1 & \\
\hline \multicolumn{7}{|l|}{ Matrimonial status } \\
\hline Married & 280 & 73 & $1.258(0.854-1.853)$ & 0.246 & & \\
\hline Unmarried & 186 & 61 & 1 & & & \\
\hline \multicolumn{7}{|l|}{ Localities } \\
\hline Bandjoukro-Bombekro & 14 & 5 & $1.683(0.456-6.220)$ & 0.435 & & \\
\hline Batera & 101 & 34 & $1.587(0.643-3.97)$ & 0.316 & & \\
\hline Binao 2 & 21 & 6 & $1.347(0.398-4.562)$ & 0.632 & & \\
\hline Boussoukro & 64 & 20 & $1.473(0.565-3.839)$ & 0.428 & & \\
\hline Ndrikro & 97 & 21 & $1.021(0.398-2.618)$ & 0.966 & & \\
\hline Niamazra & 136 & 41 & $1.421(0.585-3.451)$ & 0.437 & & \\
\hline Offa & 33 & 7 & 1 & & & \\
\hline \multicolumn{7}{|l|}{ Source of drinking } \\
\hline water & 85 & 19 & $1.350(0.787-2.316)$ & 0.275 & & \\
\hline Boreholes & 381 & 115 & 1 & & & \\
\hline Hand-dug wells & & & & & & \\
\hline
\end{tabular}

OR: Odds Ratio - a: Bivariate relationship with the dependent variable; b: Multiple logistic regression with coefficients adjusted for all other variables in the model; CI: Confidence Interval; $1=$ Reference; $*$ Significant at $\mathrm{P}$ value $<0.05$; 
Table 5. (Continued)

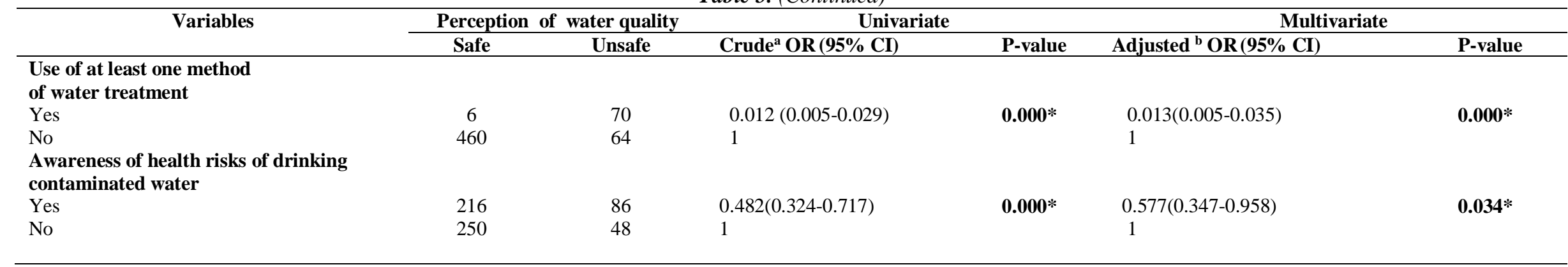

OR: Odds Ratio - a: Bivariate relationship with the dependent variable; b: Multiple logistic regression with coefficients adjusted for all other variables in the model; CI: Confidence Interval; 1 = Reference; * Significant at $\mathrm{P}$ value $<0.05$ 


\section{Discussion}

Access to safe water and sanitation facilities as well as knowledge of proper hygiene practices, can reduce the risk of illness and death from waterborne diseases. Diarrheal diseases are caused by ingestion of water contaminated with fecal pathogens contained in human or animal excreta. The purpose of this study was to explore in-depth the perceptions of drinking water quality and how this impacts on their behaviors towards water treatment and waterborne diseases. The sociological survey revealed that women accounted for $89 \%$ of those surveyed. This rate reflects the higher influence of women in household water supply decisions. This high proportion is explained by the fact that in the study area, women are responsible for the management and collection of water in households.

This observation was also made by Spence and Walters (2012) in Canada, who reported that the high proportion of women interviewed is due to the fact that they are the ones who often direct the supply and management of drinking water in households.

In a typical African community, there is a near strict division of labor in households in relation to water fetching, cooking, and farming activities. The first two is almost exclusively reserved for women while the last is for men. This has implications on planning for water supply. A meaningful water supply strategy in the rural areas must therefore involve more women than men because these are the group that is more conversant with the existing water problems and coping strategies in their communities. Respondents who did not attend school (65.5\%) and those with primary education $(21.7 \%)$ were more represented. The high illiteracy rate in the study area may favor behaviors that will compromise the hygienic quality of drinking water. The most represented age was between 20 and 40 years. These observations have also been made by some authors such as Sokegbe et al. (2017).

In the present study, more than half of the total respondents $(82.7 \%)$ indicated hand-dug wells as the source of the water they used most frequently, while borehole was the least frequently used (17.3\%). According to INS (2012), hand-dug wells are an unimproved water source. They are also classified as an unprotected water source because of their construction and design, which limits the protection of water from contamination, particularly by fecal matter, thus, posing a health risk for the population (CAWST, 2009). This high rate could be explained by the lack of a public water supply network, insufficient number of boreholes, long queues to access drilling water, frequent breakdowns, and distance between the borehole and the concession. Access to a water source is assessed in relation to the distance between the residence and the supply point, and the time set to get water. A total $77.7 \%$ of respondents were very satisfied with the quality of their drinking water. These results are opposed to those of Akple et al. (2011) in Ghana. In their study, 
according to majority of the respondents, water from the wells was not safe for drinking but they were forced to drink it when pipe water was not available.

Inadequate or a lack of treatment of drinking water remains a problem in rural communities. More than half of the study households $(87.3 \%)$ did not use any treatment before consuming well water. The treatment of drinking water by households, regardless of source, is not a common practice in Côte d'Ivoire in both urban and rural areas. In fact, $90 \%$ of households do not treat water before consuming it (88\% in urban areas and $91 \%$ in rural areas) (INS, 2012). Several studies have reported on the lack of water treatment (Kouakou et al., 2012; Francis et al., 2015; Amoukpo et al., 2018).

Joshi et al. (2014) found that the supposed portability of water, the high cost of the methods, and the ignorance of these methods are reasons for not treating water before its consumption. In the study area, $12.7 \%$ of the population use at least one treatment method. In the peri-urban zone in Abidjan, 3\% of the population treat water (Kouakou et al., 2012). Ndiaye et al. (2010) found that in $79 \%$ of cases studied, drinking water was treated in Senegalese rural areas. In the study area, those who treated drinking water primarily used it for purposes and in methods non-detrimental to their health (Tissue filtration, Bleach). However, these methods are used incorrectly. Most households used one method or the other. Also, most of the time, they do not use treatment methods according to the recommended procedures.

In general, the most common water treatment methods used in the rural areas of Côte d'Ivoire are adding chlorine, filtration (tissue, ceramic filter, or some other filter), boiling, and naphthalene (Kouakou et al., 2012). In the state of Katsina in Nigeria, tissue filtration is the most used method, followed by boiling and adding chlorine (Onabolu et al., 2011). In India, a study has shown that people use filtration and boiling as water treatment methods (Joshi et al., 2014). Generally, in developing countries, boiling, filtration, or chlorination are effective for improving the microbiological quality of drinking water (Clasen, 2015).

A total of $50.3 \%$ of respondents were knowledgeable about the potential damage to human health caused by water pollution accidents. Most people in the communities are aware of the health risks that contaminated drinking water poses as some residents clearly linked their diarrheal episodes to drinking water from the contaminated wells. However, knowledge on household water treatment mechanism is low and could be enhanced to increase the quality of water. Respondents mentioned diarrhea (46.3\%) and vomiting $(23.2 \%)$ as illnesses resulting from drinking contaminated water. Gastroenteritis, diarrhea, vomiting, typhoid, cholera, and various other water borne diseases are usually due to drinking contaminated water, our study is in agreement with previously published studies (Akple et al., 2011; Francis et al., 2015). 


\section{Conclusion}

Overall, our data suggest that majority of people in the rural areas of Tiasssale used ground water as the main source of drinking water. According to majority of respondents, water from the wells was safe for drinking. It also appears that very few respondents are aware of the risks of well water pollution. Variables associated with reports of a greater perception of risk for drinking water in the home included educational status, use of at least one method of water treatment at home and awareness of health risks of drinking contaminated water.

This study will help in understanding the rural masses perception of drinking water. In addition, this will also help in making public health policies related to quality drinking water. Provision of availability of clean drinking water may save the high expenditure incurred on health in underdeveloped countries.

\section{References:}

1. Amoukpo, H., Bachirou, Z.S., Diez, G., Akuesson, L., Lanignan, R., Degnonvi, H., Barogui, Y., Boni, G., Boko, M. \& Johnson, R.C. (2018). Knowledge, Attitudes and Practices of the Population of the District of Ahomadégbé (Municipality of Lalo) in Benin on Methods of Water Treatment at Home. Journal of Water Resource and Protection, $10: 251-265$.

2. Akple, M., Keraita, B., Konradsen, F. \& Agbenowu, E. (2011). Microbiological quality of water from hand-dug wells used for domestic purposes in urban communities in Kumasi, Ghana. Urban Water Journal, 8(1): 57-64.

3. Berhanu, A. \& Hailu, D. (2015). Bacteriological and Physicochemical Quality of Drinking Water Sources and Household Water Handling Practice Among Rural Communities of Bona District, Sidama ZoneZouthern, Ethiopia. Science Journal of Public Health, 3 (5): 782-789.

4. CAWST (Centre of Affordable Water and Sanitation Technology) (2009). Introduction à l'analyse de la qualité de l'eau de boisson, Manuel de formation, $195 \mathrm{p}$.

5. Clasen, T. (2015). Household Water Treatment and Safe Storage to Prevent Diarrheal Disease in Developing Countries. Current Environmental Health Reports, 2: 69-74.

6. Doria, M. F. (2010). Factors influencing public perception of drinking water quality. Water Policy, 12(1): 1-9.

7. Francis, R. M., Nagarajan, G., Sarkar, R., Mohan, R.V., Kang, G. \& Balraj, V. (2015). Perception of drinking water safety and factors influencing acceptance and sustainability of a water quality intervention in rural southern India. BMC Public Health, 15:731. 
8. INS (Institut National de la Statistique) (2012). Enquête Démographique et de Santé et à Indicateurs Multiples de Côte d'Ivoire 2011-2012.Calverton, Maryland, USA:INS et ICF International.599 p.

9. INS (2014). Recensement Général de la Population et de l'Habitat. Résultats globaux par Sous-P VF réfecture. (Côte d'Ivoire), 10 p.

10. Joshi, A., Prasad, S., Kasav, J.B., Segan, M. \& Singh, A.K. (2014). Water and Sanitation Hygiene Knowledge Attitude Practice in Urban Slum Settings. Global Journal of Health Science, $6: 23-34$.

11. Kouakou, J.G.S., Oga, S., Claon, S., Bama, M., Koua, D.M., Houénou, Y. \& Kouadio, K.L. (2012). Conditions d'accès et de stockage de l'eau: Enquête dans les ménages en zone périurbaine à Abidjan en 2010. Santé Publique, 2 (24) : 133-142.

12. Ndiaye, P., Ba, I.O., Dieng, M., Fall, C. \& Dia, A.T. (2010). Qualité de l'eau de consommation des ménages: Analyse et plan d'action en zone rurale sénégalaise. Santé Publique, 22: 193-200.

13. Nsiah-Kumi, P.A. (2008). Communicating effectively with vulnerable populations during water contamination events. Journal of Water Health, 6(1): 63-75.

14. Onabolu, B., Jimoh, O.D., Igboro, S.B., Sridhar, M.K.C., Onyilo, G. \& Ilya, R. (2011). Source to Point of Use Drinking Water Changes and Knowledge, Attitude and Practices in Katsina State, Northern Nigeria. Physics and Chemistry of the Earth, 36: 1189-1196. 1196.

15. Rojas, R.F. L. \& Megerle, A. (2013). Perception of Water Quality and Health Risks in the Rural Area of Medellín. American Journal of Rural Development, 1 (5) : 106-115.

16. Sokegbe, O.Y., Djeri, B., Kogno, E., Kangnidossou, M., Mensah, R.T., Soncy, K. \& Ameyapoh, Y. (2017). Les risques sanitaires liés aux sources d'eau de boisson dans le district $\mathrm{n}^{\circ} 2$ de Lomé-commune : cas du quartier d'Adakpamé. International Journal of Biological and Chemical Sciences, 11 (5): 2341-2351.

17. Spence, N. \& Walters, D. (2012). "Is it Safe?" Risk Perception and Drinking Water in a Vulnerable Population. The International Indigenous Policy Journal, 3(3). Retrieved from: htp://ir.lib.uwo.ca/iipj/vol3/iss3/9. 